Article

\title{
Sustainable Soil Loss Management in Tropical Uplands: Impact on Maize-Chili Cropping Systems
}

\author{
Khalid Hussain ${ }^{1,2, *(D)}$, Ayesha Ilyas ${ }^{1}$, Irshad Bibi ${ }^{3}\left(\mathbb{D}\right.$ and Thomas Hilger ${ }^{2, *}$ \\ 1 Agro-Climatology Laboratory, Department of Agronomy, University of Agriculture, \\ Faisalabad 38040, Pakistan; ayeshakhalid3053@gmail.com \\ 2 Institute of Agricultural Sciences in the Tropics (Hans-Ruthenberg-Institute) (490), \\ University of Hohenheim, 70599 Stuttgart, Germany \\ 3 Institute of Soil and Environmental Sciences, University of Agriculture Faisalabad, \\ Faisalabad 38040, Pakistan; irshad.niazi81@gmail.com \\ * Correspondence: khalid.hussain@uaf.edu.pk (K.H.); Thomas.hilger@uni-hohenheim.de (T.H.); \\ Tel.: +92-335-742-9406 (К.H.)
}

check for updates

Citation: Hussain, K.; Ilyas, A.; Bibi, I.; Hilger, T. Sustainable Soil Loss Management in Tropical Uplands: Impact on Maize-Chili Cropping Systems. Sustainability 2021, 13, 6477. https://doi.org/10.3390/su13116477

Academic Editors: Victor Rolo and Sean Clark

Received: 13 April 2021

Accepted: 1 June 2021

Published: 7 June 2021

Publisher's Note: MDPI stays neutral with regard to jurisdictional claims in published maps and institutional affiliations.

Copyright: (c) 2021 by the authors. Licensee MDPI, Basel, Switzerland. This article is an open access article distributed under the terms and conditions of the Creative Commons Attribution (CC BY) license (https:/ / creativecommons.org/licenses/by/ $4.0 /)$.

\begin{abstract}
Intensive land use with inappropriate land management is directly degrading South Asian uplands. A field trial was carried out on the uplands of Western Thailand with a 25\% slope to examine the effect of land use management on soil loss for sustainable crop production during two consecutive years (2010-2011). Various cropping systems with soil conservation practices were compared to maize sole cropping (MSC). Results revealed that soil loss was at a minimum in the intercropping system of maize-chili-hedgerows with minimum tillage and fertilization that was $50 \%$ to $61 \%$ and $60 \%$ to $81 \%$ less than MSC and the bare soil plot during both years, respectively. Yield advantage was at its maximum, as indicated by the highest land equivalent ratios of 1.28 and 1.21 during 2010 and 2011, respectively, in maize-chili-hedgerows-intercropping with minimum tillage and fertilization. The highest economic returns (5925 and 1058 euros ha ${ }^{-1}$ during 2010 and 2011, respectively) were also obtained from maize-chili-hedgerows-intercropping with minimum tillage and fertilization. Chili fresh fruit yield was maximum in the chili alone plot during both years due to the greater area under cultivation compared with intercropping. Maize-chili-hedgerows with minimum tillage and fertilization reduced soil loss and increased land productivity and net returns, indicating its promising features for sustainable crop production on uplands.
\end{abstract}

Keywords: land use options; soil conservation; intercropping; hedgerows; minimum tillage

\section{Introduction}

A large proportion of agricultural land (around 2 billion ha) in the world is already affected by soil erosion [1], whereas around 10 million hectares of land are destroyed every year due to soil erosion, directly impacting world food production [2].

The land area of Thailand is $514,000 \mathrm{~km}^{2}: 41 \%$ for agriculture, $31 \%$ for forest and $28 \%$ unclassified. Most of the small holders cultivate maize for food, while some concentrate on cash crops such as chilies. However, in both cases, cultivation is often carried out on uplands with varying slope degrees (10-40\%), which encourages deforestation and ultimately soil erosion [3]. Soil erosion has been a very common problem from decades, and concerns about conserving the soils on uplands are increasing. Soil loss is mainly caused by improper farming methods, low soil cover, extensive tillage and mono-cropping systems, whereas rainfall intensity, slope gradient, soil stability, crop management and conservation practices are considered to be the main factors that directly affect soil erosion [4-8] in Thailand and other parts of Asia. These Thai hillsides have moderate to steep (10-30\%) slopes and are dominated by natural bamboo forests.

Heavy rainfalls at the time of crop harvest or just after harvest causes soil erosion, ultimately reducing soil fertility. Land degradation and soil loss due to heavy rainfall and 
improper cropping has already affected the livelihood of the farmers and led them to adopt alternate income-generating sources rather than farming. Most farmers in the region have already left farming and started off-farm jobs in various mills, factories, and institutions. Knowledge of proper soil use and management to preserve available resources is a big challenge [9] for farming communities living in soil-loss hotspot areas.

Sustainable crop production is most important for regional food security and creating better livelihoods for the farming communities, whereas sustainable crop production on the uplands is not possible without soil conservation practices/conservation tillage. Conservation tillage has vital role in soil conservation, crop production and food security on slopes with tropical weather conditions. Conservation tillage is a noninversion tillage system in which around 30\% of crop residues are always kept on the soil surface. Cropping systems with conservation tillage/soil conservation practices directly reduce soil loss, maintain soil fertility and enhance farm productivity on uplands [5-8,10]. In Western Thailand, most of the farmers follow a mono/sole cropping system without any soil conservation practices. The crops (like maize and chili) are grown under sole cropping at a wider distance, encouraging soil loss due to heavy rainfall. Sole cropping offers limited opportunities for sustainable agricultural production, especially under degraded soil configurations with the fragile and unusual nature of tropical weather [11]. Instead of sole/monocropping, intercropping has many advantages, such as yield stability [12], efficient use of above and below ground resources, soil conservation, [13], increasing productivity and land use efficiency [14]. In addition, intercropping systems that are blended with soil conservation practices are more stable and less risky for farmers as these reduce the risk of crop damage [10]. Intercropping with soil conservation methods includes agroforestry systems, grass barriers and contour hedgerows.

Agroforestry is a land use that allows trees and crops and/or livestock production from a single piece of land to achieve ecological, economic, cultural, and environmental benefits [15]. These systems originated from developing countries, where the population pressure is high with limited land resources. They differ from traditional forestry in term of their economic and social benefits along with water and soil sustainability and act as buffers to extreme climatic conditions. Hilger et al. [16] indicated the effectiveness of hedgerows in the reduction of fertile soil loss on uplands. Slogans of proper land use and land use management for maintaining soil fertility are increasing over time in many regions of the world. This not only inspired governments but also led farmers to explore proper soil conservation practices in upland agriculture for maintaining soil productivity and structure. Similarly, various government and non-governmental organizations are also active in Thailand, creating awareness about land degradation issues among farming communities.

Minimum tillage with Jack bean relay cropping was suggested as a soil conservation combo under conservation tillage on uplands, reducing soil loss and improving crop productivity on the uplands of Northeast Thailand $[17,18]$. In minimum tillage, no tillage is carried out except for on soil where the seed is sowed while Jack bean relay cropping covers the soil during the fallow period and is also left in the field after harvest [17]. No till or minimum till can compact the soil, which can reduce soil loss but also reduce the infiltration rate of rainwater. Minimum tillage coupled with Jack bean relay cropping reduces soil compaction, increases infiltration, and reduces soil loss [18].

Farmers in upland regions are reluctant to adopt conservation practices such as hedgerows, intercropping, and minimum tillage coupled with Jack bean relay cropping, despite many benefits. They perceive that soil conservation practices increase input cost, reduce the land area of crops and increase resource competition. To address farmers' concerns about soil conservation techniques and the benefits of best-suited land use on hillsides, a field experiment was conducted on the uplands of Western Thailand with a specific objective: to explore the role of land use with soil conservation practices like intercropping, hedgerows and minimum tillage coupled with Jack bean relay cropping as conservation tillage for soil loss, water runoff reduction and yield improvement. It was hypothesized that cropping systems with hedgerows and conservation tillage (minimum 
tillage coupled with Jack bean relay cropping) with proper fertilization would reduce soil loss, as well as enhancing land productivity and net economic returns for small land holding upland farmers in Western Thailand.

\section{Materials and Methods}

\subsection{Study Site}

The experiment was performed at Ban Bo Wai Village $\left(13^{\circ} 28^{\prime} \mathrm{N}, 99^{\circ} 15^{\prime} \mathrm{E}\right)$, Ratchaburi Province, Western Thailand. The soil was loamy-skeletal, siliceous, isohyperthermic Kanhaplic Haplustults with shallow and stony nature, often prone to soil erosion. The region receives rainfall of about $1200 \mathrm{~mm}$ annually from May-October each year. The average annual temperature is about $28^{\circ} \mathrm{C}$ and $14 \mathrm{MJ} \mathrm{m}^{-2} \mathrm{~d}^{-1}$ solar radiations. Climatic variables were automatically recorded at the research site (Figure 1). Soil was analyzed for physiochemical properties, shown in Table 1. The locality is mostly hilly with moderate to steep slopes mostly covered by maize cultivation. Other crops include cassava (Manihat esculenta Crantz) and chili (Capsicum annuum L.). The cultivation of the maize crop starts just after the onset of the rainy season in June and ends in late September to mid-October.

Table 1. Main soil physiochemical properties of the study site before planting.

\begin{tabular}{|c|c|c|c|c|c|c|c|c|c|c|}
\hline $\begin{array}{l}\text { Soil } \\
\text { Depth }\end{array}$ & $\begin{array}{l}\text { * Soil } \\
\text { Texture }\end{array}$ & $\begin{array}{c}\text { Sand } \\
(\%)\end{array}$ & $\begin{array}{l}\text { Silt } \\
(\%)\end{array}$ & $\begin{array}{l}\text { Clay } \\
(\%)\end{array}$ & ${ }^{*} \mathrm{pH}$ & $\begin{array}{c}* \text { SOC } \\
\left(\mathrm{g} \cdot \mathrm{kg}^{-1}\right)\end{array}$ & $\begin{array}{l}{ }^{*} \text { Total N } \\
\left(\mathrm{g} \cdot \mathrm{kg}^{-1}\right)\end{array}$ & $\begin{array}{c}\text { Extractable P } \\
\left(\mathrm{mg} \cdot \mathrm{kg}^{-1}\right)\end{array}$ & $\begin{array}{c}\text { Extractable K } \\
\left(\mathrm{mg} \cdot \mathrm{kg}^{-1}\right)\end{array}$ & $\begin{array}{c}\text { BD } \\
\left(\mathrm{g} \cdot \mathrm{cm}^{-3}\right)\end{array}$ \\
\hline $0-15 \mathrm{~cm}$ & Loamy soil & 38.8 & 40.2 & 21 & 5.8 & 13 & 1.6 & 12.5 & 220.6 & 1.7 \\
\hline
\end{tabular}

* Soil texture was measured by the pipette method, $\mathrm{pH}$ as soil: water $=1: 1, \mathrm{SOC}=$ soil organic carbon measured by the Walkley-Black method, total nitrogen was measured by the Kjeldahl and steam distillation method, extractable P by the Bray II method, extractable K by $1 \mathrm{~N} \mathrm{NH}_{4} \mathrm{OAc}$, and $\mathrm{BD}=$ bulk density by core methods.

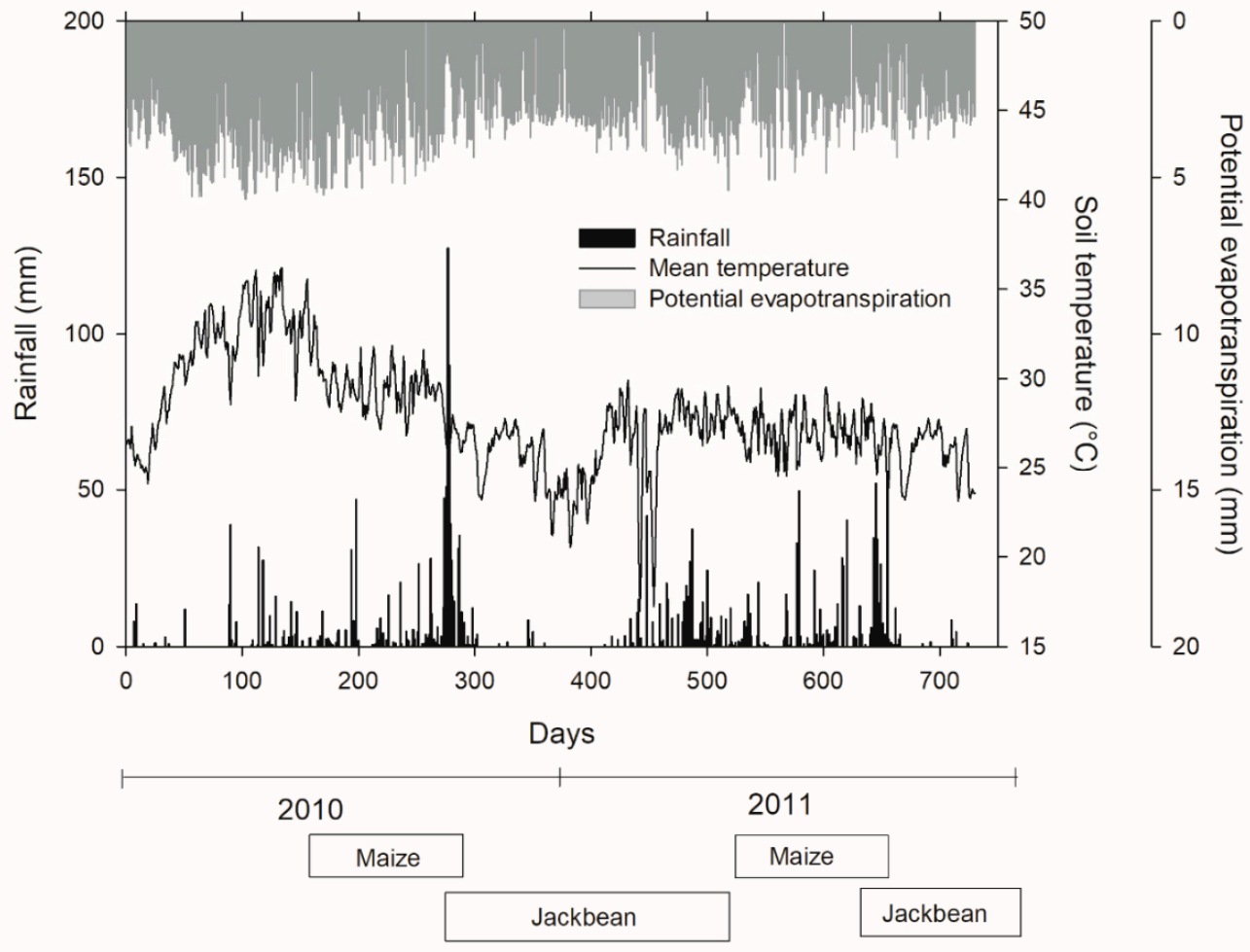

Figure 1. Climatic conditions of the study area during both years of the study.

\subsection{Experimental Layout}

The study presented here was carried out over two consecutive years of planting (2010 and 2011) on land where treatments were established in 2008-2009 to allow time for 
soil conservation treatments to express the effect. A randomized complete block design (RCBD) with three replicates was used for execution of the experiment. The plot size was $13 \mathrm{~m} \times 4 \mathrm{~m}$ with a $20-25 \%$ slope gradient. The treatments were:

T1: Maize sole cropping with tillage and fertilizer application;

T2: Maize intercropped with chilies having fertilizer application and tillage;

T3: Maize intercropped with chilies with minimum tillage, Jack bean (Canavalia ensiformis (L.) DC) relay cropping with fertilizer application;

T4: Maize intercropped with chilies and leucaena hedgerows with minimum tillage, Jack bean relay cropping with fertilizer application;

T5: like T3 with no fertilizer application;

T6: like T4 with no fertilizer application.

In addition to these treatments, two bare soil plots were also established along with two sole chili plots. Maize sowing was carried out on 22 June 2010 and 29 June 2011. One-month old chilies were also transplanted on 22 June 2010 and 29 June 2011. Tillage was carried out manually on the tillage plots to a depth of about $20 \mathrm{~cm}$, in which the soil was disturbed fully up to $20 \mathrm{~cm}$ depth, whereas minimum tillage was also practiced manually with minimal disturbance of the soil during seeding only (the upper $0-5 \mathrm{~cm}$ soil is disturbed at the place where seeds were sown). In minimum tillage treatments, all management practices from planting to harvesting were carried out with minimal soil disturbance. Jack beans were planted as relay cropping on 15 September in both years in the minimum tillage treatments only. Nitrogen was applied to the maize crop in the form of urea in two splits of $31 \mathrm{~kg} \mathrm{ha}^{-1}$ each, first at 30 days after planting and second at two months after planting. Phosphorus was applied as triple super phosphate at $22 \mathrm{~kg} \mathrm{ha}^{-1}$ and $36 \mathrm{~kg} \mathrm{ha}^{-1}$ of $\mathrm{K}$, as potassium chloride was banded at one-month after planting maize. The chilies received nitrogen at $92 \mathrm{~kg} \mathrm{ha}^{-1}$ at the time of transplanting in an equal amount to top dressing one month after transplanting. T1 had 17 maize rows, whereas every intercropping treatment had eight maize rows (two maize rows followed by two chili rows). Chili rows were six in T2, T3 and T5, while two rows were planted in T4 and T6 (Figure 2).

Maize rows were planted at a $0.75 \mathrm{~m}$ distance, while the row distance from maize to chili and the inter-row distance from chili was $1 \mathrm{~m}$, and the distance from maize to hedgerow was $0.25 \mathrm{~m}$. There were 16 maize plants per line in all treatments. Each chili row had four chili plants in the intercropping treatments. In T4 and T6, three hedgerows of $1 \mathrm{~m}$ width were planted at the top, middle and bottom end of each plot. The leucaena hedgerows were planted in 2008-2009. Hedges were pruned four times during 2010: one week after maize sowing, 30 and 60 days after maize planting and one month after maize harvest. These were pruned six times during 2011, three times before planting the maize crop in January, May, and June. The remaining prunings were carried out 30, 60 and 105 days after maize planting. Leucaena hedges were always kept to a height of $50 \mathrm{~cm}$ during the maize cropping season. Weeding was manually carried out at regular intervals in all plots. Jack beans were planted in all minimum tillage treatments, between all rows, a month before the maize harvest. During dry season, Jack beans were kept in the plots, and their remains were left as mulch on the soil surface. The maize stalks were cut and left as mulch in all treatments. The pruning material of the hedgerow treatment was uniformly dispersed within the respective plots and used as mulch. In 2010, 2.5 and $2.2 \mathrm{~kg} \mathrm{~m}^{-2}$ of leucaena residues were applied at T4 and T6, respectively, and in 2011, around 3.5 and $3.0 \mathrm{~kg} \mathrm{~m}^{-2}$ at T4 and T6, respectively. Each maize row was harvested individually in each treatment during the field experiments of 2010 and 2011. For soil loss and water runoff measurements, a collection tank $(150 \mathrm{~L})$ was connected at the base of each treatment (Figure 2). Two bare plots were also established and used as a reference for soil loss without vegetation along with a chili sole cropping plot. All the treatments have a collecting channel at the base of the plot with concrete boundaries established to keep each plot separated and to prevent water coming in and out from the sides of the plot. Measurements of soil loss and water runoff from each treatment were carried out after every rainfall event. The collection tanks were indirectly connected to treatments, with one of the outlets of 
a divisor box placed between the plot and collecting tank (Figure 2). A divisor box with equal size outlets (8 outlets) was used to minimize the quantity of runoff water going into the collecting tank, in case of heavy rainfall events. After each rainfall event, the volume of runoff water was measured by a meter rod, which was then multiplied by the number of outlets of the divisor to reach the total volume of runoff water. The quantity of lost soil was measured on the basis of suspended and heavier sediment fractions from each plot. The collecting channels developed at the lower end of each plot provided the heavy sediment fractions, which were collected and weighed, whereas suspended fractions were collected from the sediment and water collecting tanks. Thereafter, subsamples were taken and dried to obtain the dry weights of the suspended fractions.

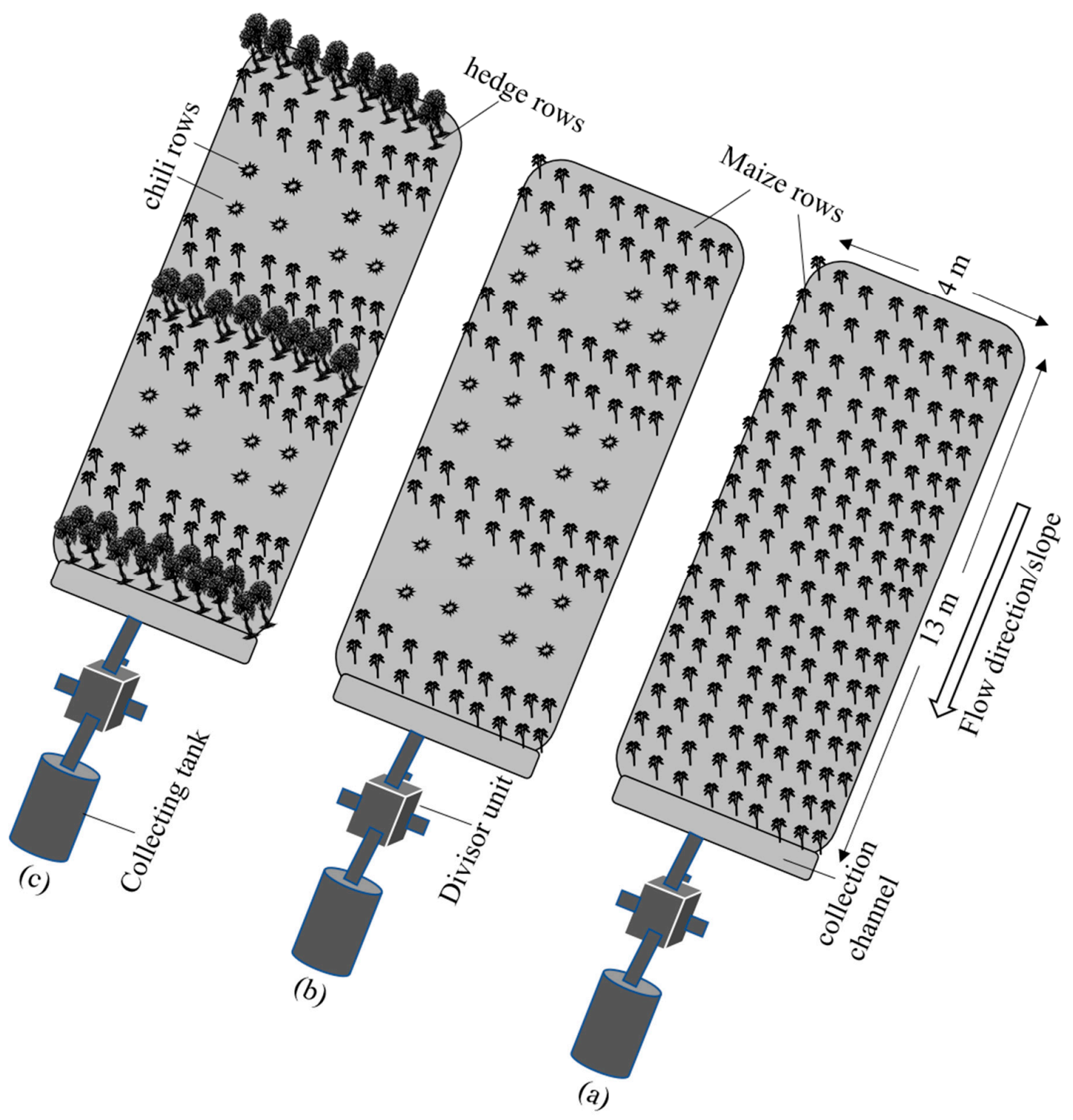

Figure 2. Experimental setup with treatment allocation (a) T1: maize mono-cropping (farmers' practice, control,) with tillage and fertilization; (b) T2: maize intercropped with chilies with fertilization and tillage; T3: maize intercropped with chilies with mini. tillage, Jack bean relay cropping with fertilizer application; T5: like T3 but without fertilizer application; (c) T4: maize intercropped with chilies and leucaena hedgerows with mini. tillage, Jack bean relay cropping with fertilizer application; T6: like T4 but without fertilizer application. 


\subsection{Productivity Evaluation}

Land equivalent ratio (LER) was used to evaluate the productivity of each cropping system. The following formula was used for LER calculations:

$$
L E R=\frac{M G Y_{1}\left(t h a^{-1}\right)}{M G Y_{S}\left(t h a^{-1}\right)}+\frac{C F Y_{1}\left(t h a^{-1}\right)}{C F Y_{S}\left(t h a^{-1}\right)}
$$

where $M G Y_{I}, M G Y_{S}, C F Y_{I}$, and $C F Y_{S}$ are the maize grain yield produced under intercropping and sole cropping, and the yield of chili fruit under intercropping and sole cropping, respectively. Two chili sole crop treatments were additionally established at the test site to provide data on the yield of sole cropped chilies for this assessment. All 17 maize rows were harvested at T1 (control), while all eight maize rows were harvested at both hedge intercrop treatments (T4 and T6). Each line was placed separately. Subsequently, samples from each line were weighed and separated into leaves, stems and grain components. Subsets from each component were dried, and above ground biomass (AGB) was calculated for each treatment. The fresh fruit yield of chilies was taken from time to time, when fruits were established from each plant. Subsequently, the area-corrected yield of maize and chili were calculated for each treatment.

Maize equivalent grain yield was computed as:

$$
E Y_{M}=M Y_{i}+\left[\left(C Y_{i} * C P\right) / M P\right]
$$

where $E Y_{M}$ is maize equivalent grain, $M Y_{i}$ is maize grain yield in intercrop, $C Y_{i}$ is chili fruit yield in intercrop, $C P$ is the price of chili fruits, and $M P$ is the price of maize grains.

\subsection{Economic Analysis}

Economic analysis of the all the treatments studied was carried out as net return/profit to estimate the economic profitability of various land use options:

$$
N R\left(E U R h a^{-1}\right)=G R\left(E U R h a^{-1}\right)-P C\left(E U R h a^{-1}\right)
$$

where NR is the Net Return, GR is the Gross Return, and PC is Production Cost. The economic analysis was carried out in euros. One EUR was equal to 40 Thai Baht during 20102011. The average price of chili fruits in 2010-11 in Thailand was 80 Thai Baht (THB) $\mathrm{kg}^{-1}$, while for maize grain, it was around $10 \mathrm{THB} \mathrm{kg}{ }^{-1}$. The average cost for maize production (sole cropping) was around 850 euros ha ${ }^{-1}, 1400$ euros ha $^{-1}$ for maize-chili-intercropping with conventional tillage, and 1100 euros ha $^{-1}$ season $^{-1}$ for maize-chili-hedgerows intercropping with minimum tillage. The above-mentioned costs of production are inclusive of all cost from sowing to harvesting.

\subsection{Statistical Analysis}

Statistical analysis was done in SAS, V-9.2 (SAS Inc., Cary, NC, USA). The RCBD was used in the field study for both years. The bare soil plot was used in soil loss comparisons, while chili sole crop plots were used to compare the chili yield under sole and intercrop conditions. Bivariate techniques were used for analyzing intercropping trials per year [19]. Pairwise comparison of treatments was carried out using Tukey's Honest Significant Difference test at $p=0.05$.

\section{Results}

\subsection{Soil Loss and Water Runoff}

Total soil loss from various land use options was statistically significant (Table 2). A maximum soil loss of $30 \mathrm{tha}^{-1}$ was observed from the bare plot, followed by T1, T2 and T5 during the 2010 growing season, whereas the minimum quantity of soil $\left(11.6 \mathrm{t} \mathrm{ha}^{-1}\right)$ was lost from fertilized-hedgerow-intercropping-minimum tillage treatment (T4). Hedgerows' inclusion within maize-chili-intercropping with fertilizer application (T4) reduced soil 
loss by $61 \%$ and $53 \%$ compared with the bare soil plot and the farmers' practice (maize alone (T1)), respectively. Moreover, hedgerows' inclusion within maize-chili intercropping without fertilizer application (T6) reduced soil loss by $50 \%$ and $39 \%$ compared with the bare soil plot and the farmers' practice (maize alone (T1)), respectively. Soil loss trends observed during the 2011 growing season were similar to those of the 2010 growing season, but the quantity of soil loss was less in 2011 compared with 2010. Maximum total soil was again lost from the bare soil plot compared with the rest of the treatments during 2011. Minimum soil $\left(3 \mathrm{t} \mathrm{ha}^{-1}\right)$ was lost from the fertilized-hedgerow-intercropping-minimum tillage treatment (T4), followed by the maize-chili intercrop with hedgerows but without fertilizer application treatment (T6) with $3.31 \mathrm{t} \mathrm{ha}^{-1}$. During the 2011 cropping season, $\mathrm{T} 4$ reduced $60 \%$ of soil loss, followed T6, which reduced soil loss by $55 \%$ compared with T1 (farmers' practice).

Table 2. Cumulative soil loss and water runoff from various maize-based cropping systems.

\begin{tabular}{ccccc}
\hline \multirow{2}{*}{ Treatments } & \multicolumn{2}{c}{ Soil Loss $\left(\mathbf{t} \cdot \mathbf{h} \mathbf{a}^{-\mathbf{1}}\right)$} & \multicolumn{2}{c}{ Water Runoff $\mathbf{~ ( m}^{\mathbf{3}} \cdot \mathbf{h a}^{\mathbf{- 1}} \mathbf{)}$} \\
\cline { 2 - 5 } & $\mathbf{2 0 1 0}$ & $\mathbf{2 0 1 1}$ & $\mathbf{2 0 1 0}$ & $\mathbf{2 0 1 1}$ \\
\hline T1 & $24.7 \mathrm{~b}$ & $7.50 \mathrm{~b}$ & 4091 & 1227 \\
T2 & $24.4 \mathrm{~b}$ & $7.70 \mathrm{~b}$ & 3955 & 1268 \\
T3 & $22.7 \mathrm{~b}$ & $7.88 \mathrm{~b}$ & 4431 & 1429 \\
T4 & $11.6 \mathrm{c}$ & $3.00 \mathrm{c}$ & 3980 & 1123 \\
T5 & $23.7 \mathrm{~b}$ & $7.92 \mathrm{~b}$ & 4004 & 1111 \\
T6 & $15.0 \mathrm{bc}$ & $3.31 \mathrm{c}$ & 3948 & 1069 \\
Chili sole crop & $22.7 \mathrm{~b}$ & $10.12 \mathrm{~b}$ & 4392 & 1533 \\
Bare soil plot & $30.0 \mathrm{a}$ & $16.10 \mathrm{a}$ & 4474 & 1681 \\
\hline$p$ value & $\leq 0.005$ & $\leq 0.05$ & $\mathrm{NS}$ & $\mathrm{NS}$ \\
\hline
\end{tabular}

Figures with different small letters are indicating statistically significant differences between the treatments. T1: maize mono-cropping (farmers' practice, control,) with tillage and fertilization; T2: maize intercropped with chilies with fertilization and tillage; T3: maize intercropped with chilies with mini. tillage, Jack bean relay cropping with fertilizer application; T4: maize intercropped with chilies and leucaena hedgerows with mini. tillage, Jack bean relay cropping with fertilizer application; T5: like T3 but without fertilizer application; T6: like T4 but without fertilizer application.

Water runoff measurements also showed statistically significant differences among various land use options during both years (Table 2). During 2010, maximum total water runoff $\left(4474 \mathrm{~m}^{3} \mathrm{ha}^{-1}\right)$ was observed in the bare soil plot, which was 9.4, 13.1, 0.97, 12.4, 11.7, 13.3 and $1.87 \%$ higher compared with $\mathrm{T} 1, \mathrm{~T} 2, \mathrm{~T} 3, \mathrm{~T} 4, \mathrm{~T} 5, \mathrm{~T} 6$ and chili sole cropping, respectively. The lowest water runoff during 2010 was observed in both maize-chiliintercropping with hedgerows and with and without fertilizer application treatments (T4 and T6, respectively). In 2011, the total water runoff was similar to that of 2010 . Maximum water runoff $\left(1681 \mathrm{~m}^{3} \mathrm{ha}^{-1}\right)$ was observed in the bare soil plot as observed in 2010. Total water runoff from the bare soil plot was $37,32.5,17.6,49.6,51.3,57.2$ and $9.7 \%$ greater than T1, T2, T3, T4, T5, T6 and chili sole cropping, respectively.

Soil loss measured after each rainfall event during both years from each treatment showed variable trends (Figure 3). All treatments showed variable trends of cumulative soil loss. During early 2010, cumulative soil loss trends were similar with the onset of the rainy season, but later, variability among the treatment increased. Maximum cumulative soil loss during all rainfall events was observed in the bare plot closely followed by the maize alone plot (T1), whereas minimum cumulative soil loss after each rainfall event occurred in the maize-chili intercrop with hedgerow treatment with and without fertilizer application (T4 and T6). Event-based soil loss was maximum at the end of the growing season in all treatments when there were heavy rainfall events. Overall cumulative soil loss in intercrop treatments was lower than in maize sole cropping and the bare soil plot during 2010. 


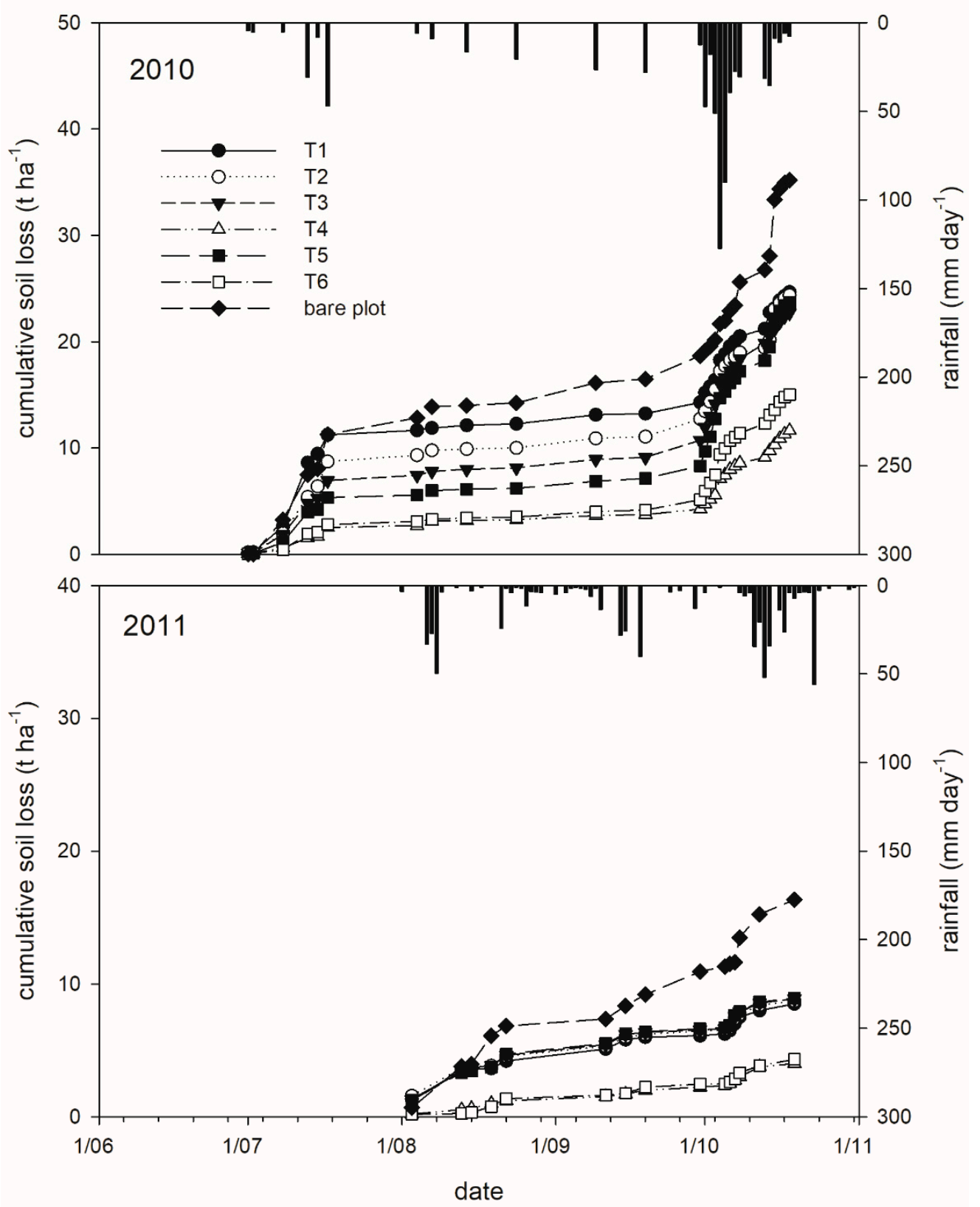

Figure 3. Time series cumulative soil loss from various maize-based cropping systems, T1: Maize monocropping (farmers' practice, control,) having tillage, and fertilization; T2: Maize intercropped with chilies having fertilization and tillage; T3: Maize intercropped with chilies having mini. tillage, Jack bean relay cropping with fertilizer application; T4: Maize intercropped with chilies and leucaena hedgerows having mini. tillage, Jack bean relay cropping with fertilizer application; T5: like T3 but without fertilizer application; T6: like T4 but without fertilizer application.

Cumulative soil loss in all the treatments during 2011 was lower than that of 2010. There were three distinct sets of cumulative soil loss trends in 2011. The highest soil loss occurred in bare plot soil after each rainfall event, followed by maize alone and intercrop treatments with minimum tillage and Jack bean relay cropping (T1, T2, T3, and T5), whereas the lowest cumulative soil loss at each rainfall event was observed in T4 and T6. 


\subsection{Maize Yield $\left(t h a^{-1}\right.$ )}

Maize-based cropping systems significantly affected maize grain, equivalent and biological yield (area corrected) (Table 3). Maize grain yield ranged from 2.45 to $6.86 \mathrm{tha}^{-1}$ during the 2010 growing season. The maize sole cropping treatment (T1) attained the highest grain yield statistically, compared with the rest of the treatments $(p<0.001)$. Fertilized-hedgerow-intercropping-minimum tillage (T4) yield was highest among all the intercrop treatments, closely followed by T6, which was statistically on par. The lowest grain yield was observed in T5, which was statistically on par with that of T5. During 2011, T1 produced the highest grain yield statistically, compared with the rest of the treatments, but was lower compared with 2010. T4 produced the highest grain yield statistically among intercrop treatments, which was greater than 2010. The lowest grain yield was observed in T5. Maize equivalent grain yield was at its maximum $\left(19.48 \mathrm{t} \mathrm{ha}^{-1}\right)$ under maizechili intercrop conditions (T2), whereas both intercrop treatments with soil conservation treatments T3 and T4 were statistically on par with equivalent yields of $14.78 \mathrm{tha}^{-1}$ and $14.77 \mathrm{t} \mathrm{ha}^{-1}$, respectively, during 2010. The lowest maize equivalent yield was $10.94 \mathrm{t} \mathrm{ha}^{-1}$, observed in T6. During 2011, the maximum maize equivalent grain yield $\left(6.91 \mathrm{t} \mathrm{ha}^{-1}\right)$ was observed in T4, which was statistically on par with T2. Minimum maize equivalent grain yield $\left(4.94 \mathrm{tha}^{-1}\right)$ was observed in $\mathrm{T} 5$.

Table 3. Maize grain, biological and equivalent yield, chili fresh fruit yield and land equivalent ratio obtained from various maize-based cropping systems.

\begin{tabular}{|c|c|c|c|c|c|c|c|c|c|c|}
\hline \multirow{2}{*}{ Treatments } & \multicolumn{2}{|c|}{$\begin{array}{l}\text { Maize Grain Yield } \\
\qquad\left(\mathrm{t} \cdot \mathrm{ha}^{-1)}\right.\end{array}$} & \multicolumn{2}{|c|}{$\begin{array}{l}\text { Maize Biological Yield } \\
\left(\mathrm{t} \cdot \mathrm{ha}^{-1}\right)\end{array}$} & \multicolumn{2}{|c|}{$\begin{array}{l}\text { Maize Equivalent Grain Yield } \\
\qquad\left(t \cdot h a^{-1}\right)\end{array}$} & \multicolumn{2}{|c|}{$\begin{array}{l}\text { Chili Fresh Fruit Yield } \\
\qquad\left(\mathrm{t} \cdot \mathrm{h} \mathrm{a}^{-1)}\right.\end{array}$} & \multicolumn{2}{|c|}{$\begin{array}{l}\text { Land Equivalent } \\
\text { Ratio }\end{array}$} \\
\hline & 2010 & 2011 & 2010 & 2011 & 2010 & 2011 & 2010 & 2011 & 2010 & 2011 \\
\hline $\mathrm{T} 1$ & $6.86 \mathrm{a}$ & $6.41 \mathrm{a}$ & $14.97 \mathrm{a}$ & $11.84 \mathrm{a}$ & - & - & - & - & $1.00 \mathrm{c}$ & $1.00 \mathrm{~b}$ \\
\hline $\mathrm{T} 2$ & $3.06 \mathrm{c}$ & $2.97 \mathrm{~d}$ & $6.84 b$ & $5.46 \mathrm{~b}$ & $19.48 \mathrm{a}$ & $6.54 \mathrm{a}$ & $3.28 \mathrm{~b}$ & $0.71 \mathrm{~b}$ & $1.23 \mathrm{a}$ & $1.17 \mathrm{a}$ \\
\hline T3 & $2.57 \mathrm{~d}$ & $2.69 \mathrm{e}$ & $5.55 \mathrm{c}$ & $4.97 c$ & $14.78 \mathrm{~b}$ & $5.79 \mathrm{~b}$ & $2.44 \mathrm{c}$ & $0.62 c$ & $1.08 \mathrm{~b}$ & $1.03 \mathrm{~b}$ \\
\hline $\mathrm{T} 4$ & $3.33 \mathrm{~b}$ & $3.78 \mathrm{~b}$ & $6.71 \mathrm{~b}$ & $5.51 \mathrm{~b}$ & $14.77 \mathrm{~b}$ & $6.91 \mathrm{a}$ & $2.29 c$ & 0.62 c & $1.28 \mathrm{a}$ & $1.21 \mathrm{a}$ \\
\hline $\mathrm{T} 5$ & $2.45 \mathrm{~d}$ & $2.33 \mathrm{f}$ & $5.03 \mathrm{c}$ & $4.13 \mathrm{c}$ & $13.06 \mathrm{c}$ & $4.94 \mathrm{c}$ & $2.12 \mathrm{c}$ & $0.52 \mathrm{~cd}$ & $0.90 \mathrm{~d}$ & $0.88 \mathrm{c}$ \\
\hline T6 & $3.31 \mathrm{~b}$ & $3.25 c$ & $6.61 \mathrm{~b}$ & $4.83 c$ & $10.94 \mathrm{~d}$ & $5.46 \mathrm{~b}$ & $1.52 \mathrm{~d}$ & $0.44 \mathrm{~d}$ & $0.92 \mathrm{~d}$ & $0.94 \mathrm{c}$ \\
\hline CSC & - & - & - & - & - & - & $6.47 \mathrm{a}$ & $1.19 \mathrm{a}$ & $1.00 \mathrm{c}$ & $1.00 \mathrm{~b}$ \\
\hline$p$ value & $\leq 0.005$ & $\leq 0.05$ & $\leq 0.005$ & $\leq 0.005$ & $\leq 0.05$ & $\leq 0.05$ & $\leq 0.005$ & $\leq 0.005$ & $\leq 0.005$ & $\leq 0.05$ \\
\hline
\end{tabular}

Figures with different small letters indicate statistically significant differences between treatments. T1: maize mono-cropping (farmers' practice, control,) with tillage and fertilization; T2: maize intercropped with chilies with fertilization and tillage; T3: maize intercropped with chilies with mini. tillage, Jack bean relay cropping with fertilizer application; T4: maize intercropped with chilies and leucaena hedgerows with mini. tillage, Jack bean relay cropping with fertilizer application; T5: like T3 but without fertilizer application; T6: like T4 but without fertilizer application; CSC: chili sole cropping.

Maize biological yield was statistically highest in T1, closely followed by T2, which was statistically on par with that of T4 during the 2010 growing season. The lowest maize biological yield ( $5.03 \mathrm{t} \mathrm{ha}^{-1}$ ) was attained by $\mathrm{T} 5$, which was statistically on par with $\mathrm{T} 3$. Similar trends of statistically significant biological yield were observed during 2011 but were lower than 2010 in all treatments.

\subsection{Chili Yield $\left(t h a^{-1}\right)$}

Chili fresh fruit yield was statistically significant in both growing seasons (Table 3). During 2010, chili sole cropping produced the highest chili fresh fruit yield statistically, compared with intercropping treatments with and without soil conservation techniques. Among intercrop treatments, T2 produced a higher chili fresh fruit yield, while the lowest chili fresh fruit yield was observed in T6, where chili was intercropped with maize and hedgerows with zero fertilization. During 2011, maximum chili yield was obtained from chili sole cropping as observed during the 2010 growing season. Moreover, chili production under the intercrop condition was at its maximum in T2, where chili was intercropped with maize, minimum tillage and fertilizer application, while minimum chili fresh fruit yield was observed in T6, as observed in 2010. Overall, chili fresh fruit yield was many 
folds higher during 2010 compared with the 2011 growing season in all treatments due to an insect attack.

\subsection{Cropping System Productivity Evaluation and Economic Analysis}

Cropping system productivity evaluation was carried out by calculating the land equivalent ratio (Table 4). During 2010, statistical analysis showed that the maximum land equivalent ratio (1.28) was observed in maize-chili-intercropping with leucaena hedges, minimum tillage, Jack bean relay and fertilizer application (T4), which was statistically on par with maize-chili-intercropping (T2). The lowest land equivalent ratio (0.90) was observed in T5, which was statistically on par with maize-chili-intercropping with leucaena hedges, minimum tillage, and Jack bean relay but without fertilizer application (T6). Similar trends of land equivalent ratios were observed during 2011, while the values were slightly lower than in 2010. Statistical analysis showed that the maximum land equivalent ratio (1.21) was observed in maize-chili-intercropping with leucaena hedges, minimum tillage, Jack bean relay and fertilizer application (T4), which was statistically on par with maizechili-intercropping (T2). The lowest land equivalent ratio (0.88) was observed in T5, which was statistically on par with maize-chili-intercropping with leucaena hedges, minimum tillage, and Jack bean relay but without fertilizer application (T6).

Table 4. Economic analysis of investigated land use treatments during both cropping seasons.

\begin{tabular}{cccccc}
\hline Treatments & Maize Return & Chili Fruit Return & Gross Return & Production Cost & Net Return \\
\hline 2010 & & & & \\
\hline T1 & 1715 & - & 1715 & 850 & 865 \\
T2 & 765 & 6560 & 7325 & 1400 & 5925 \\
T3 & 643 & 4880 & 5523 & 1100 & 4423 \\
T4 & 833 & 4580 & 5413 & 1100 & 4313 \\
T5 & 613 & 4240 & 4853 & 1100 & 3753 \\
T6 & 828 & & 3868 & 1100 & 2768 \\
2011 & & - & & 850 & \\
T1 & 1603 & 1420 & 1603 & 1400 & 753 \\
T2 & 743 & 1240 & 2163 & 1100 & 763 \\
T3 & 673 & 1240 & 2185 & 113 \\
T4 & 945 & 1040 & 1623 & 1100 & 1085 \\
T5 & 583 & 880 & 1693 & 523 \\
T6 & 813 & & & 593
\end{tabular}

The cost and net return values present in the table are Euros/hectare (1 Euro = 40 Baht). T1: maize mono-cropping (farmers' practice, control,) with tillage and fertilization; T2: maize intercropped with chilies with fertilization and tillage; T3: maize intercropped with chilies with mini. tillage, Jack bean relay cropping with fertilizer application; T4: maize intercropped with chilies and leucaena hedgerows with mini. tillage, Jack bean relay cropping with fertilizer application; T5: like T3 but without fertilizer application; T6: like T4 but without fertilizer application.

The crops present in the intercropping condition provided greater economic returns compared with farmers' practice (Table 4). During 2010, maximum net return (EUR 5925) was obtained from T2, followed by T3, T4, T5 and T6, respectively, while the lowest net return (865 EUR) was obtained from T1, where maize was planted as sole cropping, whereas, during 2011, maize-chili-intercropping with leucaena hedgerows and fertilizer application (T4) produced the highest net return value (EUR 1085) followed by T1. Minimum net return was obtained from T5. Economic analysis of the land use options also indicated that the net return values were higher during 2010 compared with 2011.

\section{Discussion}

\subsection{Effect of Various Land Use Options on Soil Loss and Water Runoff Dynamics}

Soil health is essential for sustainability productivity. In Thailand, no strict laws are available to restrict farmers using uplands without thinking about soil health. Soil degradation has accelerated over the last decade [20]. Maize sole cropping (T1) reduced soil loss by around $18-50 \%$ compared with the bare soil plot during 2010-2011, respectively. This reduction in soil loss was due to soil covered by maize plants. Soil loss between 
$\mathrm{T} 1$ and intercrop treatments with and without conservation tillage were non-significant. This means that intercropping and minimum tillage effects were like maize sole cropping and tillage. Maize was planted in rows $75 \mathrm{~cm}$ apart, which provided enough soil cover to reduce soil loss compared with intercropping with conservation tillage. In intercropping treatments, maize rows were planted at $75 \mathrm{~cm}$ apart, but chili rows were planted $1 \mathrm{~m}$ apart, which favored soil loss even under conservation tillage.

On the other hand, intercropping treatments with hedgerows and conservation tillage practices (T4) reduced soil loss by many folds $(61.33 \%$ and $53 \%)$ compared with the bare soil plot and farmers' practice (T1) during both growing seasons. Hedgerows reduced soil loss in two ways: first, Leucaena pruning provided the soil with additional cover, which reduced the direct abrasion of splash raindrops; and second, it enhanced the organic matter of the soil. Minimum tillage directly reduces soil loss compared with conventional tillage [21]. In maize alone (T1), the soil was tilled, which may have also reduced the soil's capacity to conserve moisture to some extent and may have facilitated soil loss, while minimum tillage associated with Jack bean relay cropping and subsequent mulching with leucaena hedgerow pruning in the soil conservation treatment may have improved soil structure, which reduced soil loss [18]. Better moisture conservation by hedgerows as they slowed down water runoff additionally facilitated water infiltration and ultimately reduced soil loss [5,17].

Cropping systems with soil conservation practices and conservation tillage may create sustainability in production, plays an important role in increasing land use efficiency on a long-term basis, and has increased interest of the farmers due to its potential benefits of increasing yields and reduction of soil erosion risks. Pansak et al. [17] indicated that intercropping systems with leucaena hedgerows along with conservation tillage (minimum tillage and Jack bean relay cropping) not only reduced soil loss but also water runoff, except during the hedgerows' establishment phase.

\subsection{Effect of Land Use Options on Crop Productivity}

Low maize yield in all the treatments during 2011 was due to reduction in soil fertility due to fertile soil loss over time compared with 2010 (Table 2). Most cultivation on uplands is carried out on freshly cleared forests, and it has been observed that, over time, the fertility of land decreases because of land mismanagement (heavy tillage/conventional tillage), high loss of fertile topsoil, low fertilizer inputs and intensive land use.

Soil analysis data of the field experiment showed reductions for organic matter and extractable P from 2010 to 2011 (2010: $10.6 \mathrm{mg} \mathrm{kg}^{-1}$ extractable P, 1.97\% soil organic matter vs. 2011: $9.5 \mathrm{mg} \mathrm{kg}^{-1}$ extractable $\mathrm{P}, 1.76 \%$ soil organic matter at a soil depth of $0-45 \mathrm{~cm}$ ) [10]. This argument was further supported by the grain nitrogen concentration values of the same experiment, which were lower in 2011 compared with 2010 [6]. Grain nitrogen concentration is directly related to nitrogen availability and its utilization. If there is low availability of nitrogen, then the uptake of plants is low, and low concentrations are found in the grains.

Maize grain and biological yield were highest in maize alone/farmers' practice land use due to the optimum area under the maize crop. Whereas land use options with intercropping and soil conservation practices occupied some space, which reduced the area under the maize crop but was compensated with the yield of the intercrop, which increased land use efficiency. Among intercropping land use options (T2-T6), maximum maize grain yield and biological yield were observed in T4, where maize was intercropped with chili along with soil conservation practices (hedgerows and minimum tillage) during both years, closely followed by T6 and T2. Soil conservation methods with minimum tillage or no tillage can reduce fertile soil loss [21], which ensures sustainable crop production. The lower values of the equivalent maize grain yield during 2011 were due to lower chili fresh fruit yield because chili plants were infested by cercospora leaf spot at around 15-20 days after transplanting, which later created defoliation of chili plants [5,7,8]; similarly, it also reduced the net economic return. 
The intercropping of maize with chili in soil conservation practices was economically and environmentally viable on uplands for crop production, indicated by the high values of maize equivalent grain yield under intercrop land use options [22]. Moreover, conservation agricultural practices always have a positive impact on system productivity [23]. Land use options with intercropping in soil conservation practices would provide a sustainable solution to soil loss management on uplands with economic benefits. The soil conservation measures improved soil fertility, lowered soil loss and also provided higher organic inputs from leucaena prunings and Jack bean harvest residues, and additional $\mathrm{N}$ through biological $\mathrm{N}$ fixation by Leucaena leucocephala hedgerows $\left(28 \mathrm{~kg} \mathrm{ha}^{-1} \mathrm{y}^{-1} \mathrm{~N}\right.$ added to soil as biological fixed nitrogen).

Crop productivity was good even under non-fertilized land use treatments with and without hedgerows, probably due to minimum tillage associated with legume relay cropping, which enhanced the organic matter of the plots by biological $\mathrm{N}$ fixation and residue incorporation [24]. Positive effects of minimum tillage in combination with mulching and growing a relay cover crop (legumes) on crop yield have been documented in several studies [25,26]. Moreover, chili fresh fruit yield compensated maize production in intercrop and soil conservation practices (with hedgerows) and fertilizer application. Zuazo et al. [27] and Quinkenstein et al. [28] testified that grass barriers and hedgerows are quite effective for soil conservation and sustainable agricultural production on slopes.

Farmers' choice of cultivation on the uplands of Western Thailand depended on two main points: the first focus is household food security, and the second focus is the market demand of a specific crop. Most smallholders grow maize as domestic food, while some also concentrate on growing cash crops like chilies due to their high market value. Wider space between chili plants and rows $\left(1 \mathrm{~m}^{2}\right)$ makes the soil prone to soil loss if chili is grown alone as sole crop. In this study, we successfully practiced intercropping with soil conservation practice to provide an option for farmers to grow both food for their families in terms of maize grain and earn cash by selling green chilies without compromising through loss of land resources. Maximum chili yield was obtained in the intercrop treatment with soil conservation practice is another indication of sustainable soil productivity in soil conservation land use treatments. [5], while carrying out productivity analysis of the same treatments indicated that all intercrop treatments with fertilizer application showed that 3 to $21 \%$ more land area would be required for a sole cropping system to reach the yield of an intercropping system $[25,29]$. Higher land equivalent ratios are an indication of the yield advantage of intercropping over sole stands due to the judicious use of available environmental and land resources for plant growth [11].

\subsection{Crop Productivity Evaluation and Economic Return}

The land equivalent ratios (LER) were higher than 'one' in fertilized intercropping systems during both years (Table 3 ). This is an indication of yield advantage over sole cropping conditions. This was attributed to the judicious utilization of water, light and nutrients for plant growth [11]. Land equivalent ratios of T2 to T4 were 1.08 to 1.28 in 2010 and 1.03 to 1.21 in 2011, indicating a better LUE of intercrops than those of sole crops. This means 8 to $28 \%$ and 3 to $21 \%$ extra land is required by a sole-cropped system to attain yield equal to an intercropping system [30,31]. This is a clear indication of better land resource utilization in intercropping systems compared with sole/monocropping. Higher values of LER in maize-chili-intercropping with leucaena hedgerows, minimum tillage, Jack bean relay cropping and proper fertilizer application (T4) would be convincing for upland farmers to adopt these types of cropping systems to increase land productivity along with soil conservation.

Modern agriculture around the globe is focused on economics. Sustainable production and economic profitability gains are more important when the land holding is small. The intercropping systems with soil conservation techniques showed greater net returns compared with sole cropping conditions due to better market incentives for chili as a cash crop (Table 3). Earlier studies carried out in various environments also mentioned the 
superiority of intercropping in raising farm income and soil fertility restoration compared with the mono/sole cropping of component crops [14], because chili and maize grains are an important part of daily cuisines in Thailand. Chili is consumed in its fresh and dried forms and has the highest market value due to its high consumption, which increases the net return of soil-conservation-based intercropping land uses. The net return was less during 2011 due to the infestation of chili plants by cercospora leaf spot around three weeks after transplanting, which led to the defoliation of chili plants and ultimately reduced chili yield [5].

\section{Conclusions}

The role of cropping systems in conservation practices is very crucial in reducing soil loss and improving sustainable crop production on uplands. Fertilized-hedgerowintercropping with minimum tillage reduced fertile soil loss, which ensured sustainable crop production. Minimum tillage and Jack bean relay cropping proved to be the best conservation option on the tropical uplands for reducing soil loss, increasing land utilization and economic returns. They acted as a buffer against soil loss and water runoff to save the fertile topsoil and optimize the soil moisture conditions for sustainable crop production on the uplands. Experiments emphasizing the nuances of land use with soil conservation options are useful for yield maximization and livelihood uplift for upland farming communities in Southeast Asia. Long-term experiments on crop production with soil conservation on uplands should be initiated locally at a government level to address farmers' concerns that are visualized while practicing soil conservation techniques during cropping. This will ultimately enhance confidence in farmers to use soil conservation techniques for sustainable crop production on uplands.

Author Contributions: K.H. and T.H. planned the experiments, K.H. conducted experiments, K.H., A.I., I.B. and T.H. interpreted the results and made the writeup. All authors have read and agreed to the published version of the manuscript.

Funding: The funding for the study was provided by K.U. Leuven under project OT/07/045.

Institutional Review Board Statement: Not applicable.

Informed Consent Statement: Not applicable.

Data Availability Statement: The data presented in this study are available on request from the corresponding author.

Acknowledgments: We would like to thank K.U. Leuven for funding field research under project OT/07/045, the University of Agriculture, Faisalabad for supporting first author stay in Germany and the Forschungszentrum Jülich $\mathrm{GmbH}$ for providing the equipment. We also extend gratitude's to Thanuchai Kongkaew (who passed away on 16 February 2012) for supporting field experiments and student's facilitation during field campaigns in Thailand.

Conflicts of Interest: The authors confirm that there is no conflict of interest with the networks, organizations and data centers referred in the manuscript.

\section{References}

1. Hillel, D.; Hatfield, J.L. Encyclopedia of Soils in the Environment; Elsevier: Amsterdam, The Netherlands, 2005 ; Volume 3.

2. Pimentel, D.; Burgess, M. Soil Erosion Threatens Food Production. Agriculture 2013, 3, 443-463. [CrossRef]

3. Forsyth, T. Sustainable Livelihood Approaches and Soil Erosion Risks: Who Is to Judge? Int. J. Soc. Econ. $2007,34,88-102$. [CrossRef]

4. Bahadur, K.C.K. Mapping Soil Erosion Susceptibility Using Remote Sensing and GIS: A Case of the Upper Nam Wa Watershed, Nan Province, Thailand. Environ. Geol. 2009, 57, 695-705. [CrossRef]

5. Hussain, K.; Wongleecharoen, C.; Hilger, T.; Vanderborght, J.; Garré, S.; Onsamrarn, W.; Sparke, M.-A.; Diels, J.; Kongkaew, T.; Cadisch, G. Combining $\delta 13 \mathrm{C}$ Measurements and ERT Imaging: Improving Our Understanding of Competition at the Crop-Soil-Hedge Interface. Plant Soil 2015, 393, 1-20. [CrossRef]

6. Hussain, K.; Wongleecharoen, C.; Hilger, T.; Ahmad, A.; Kongkaew, T.; Cadisch, G. Modelling Resource Competition and Its Mitigation at the Crop-Soil-Hedge Interface Using WaNuLCAS. Agroforest. Syst. 2016, 90, 1025-1044. [CrossRef] 
7. Hussain, K.; Ilyas, A.; Wajid, A.; Ahmad, A.; Mahmood, N.; Hilger, T.; Kongkaew, T. Alley Cropping Simulation: An Opportunity for Sustainable Crop Production on Tropical Uplands. Pak. J. Agric. Sci. 2019, 56, 109-112. [CrossRef]

8. Hussain, K.; Ilyas, A.; Wongleecharoen, C.; Hilger, T.; Wajid, A.; Ahmad, A.; Cadisch, G. Sustainable Land Use Options for Optimum Resources Use in Maize Based Cropping System on Uplands of Western Thailand. Agroforest. Syst. 2020, 94, 2289-2300. [CrossRef]

9. Frene, J.P.; Gabbarini, L.A.; Wall, L.G. Soil Physiology Discriminates between No-till Agricultural Soils with Different Crop Systems on Winter Season. Soil Use Manag. 2020, 36, 571-580. [CrossRef]

10. Hussain, K. Measuring and Modelling Resource Use Competition at the Crop-Soil-Hedge Interface on a Hillside in Western Thailand. Ph.D. Thesis, University of Hohenheim, Stuttgart, Germany, 2015.

11. Banik, P.; Sasmal, T.; Ghosal, P.K.; Bagchi, D.K. Evaluation of Mustard (Brassica Compestris Var. Toria) and Legume Intercropping under 1:1 and 2:1 Row-replacement Series Systems. J. Agron. Crop Sci. 2000, 185, 9-14. [CrossRef]

12. Lithourgidis, A.S.; Vlachostergios, D.N.; Dordas, C.A.; Damalas, C.A. Dry Matter Yield, Nitrogen Content, and Competition in Pea-Cereal Intercropping Systems. Eur. J. Agron. 2011, 34, 287-294. [CrossRef]

13. Javanmard, A.; Nasab, A.D.M.; Javanshir, A.; Moghaddam, M.; Janmohammadi, H. Forage Yield and Quality in Intercropping of Maize with Different Legumes as Double-Cropped. J. Food Agric. Environ. 2009, 7, 163-166.

14. Maitra, S.; Hossain, A.; Brestic, M.; Skalicky, M.; Ondrisik, P.; Gitari, H.; Brahmachari, K.; Shankar, T.; Bhadra, P.; Palai, J.B.; et al. Intercropping-A Low Input Agricultural Strategy for Food and Environmental Security. Agronomy 2021, 11, 343. [CrossRef]

15. Sollen-Norrlin, M.; Ghaley, B.B.; Rintoul, N.L.J. Agroforestry Benefits and Challenges for Adoption in Europe and Beyond. Sustainability 2020, 12, 7001. [CrossRef]

16. Hilger, T.; Keil, A.; Lippe, M.; Panomtaranichagul, M.; Saint-Macary, C.; Zeller, M.; Pansak, W.; Dinh, T.V.; Cadisch, G. Soil Conservation on Sloping Land: Technical Options and Adoption Constraints. In Sustainable Land Use and Rural Development in Southeast Asia: Innovations and Policies for Mountainous Areas; Springer: Berlin/Heidelberg, Germany, 2013; pp. 229-279.

17. Pansak, W.; Hilger, T.H.; Dercon, G.; Kongkaew, T.; Cadisch, G. Changes in the Relationship between Soil Erosion and N Loss Pathways after Establishing Soil Conservation Systems in Uplands of Northeast Thailand. Agric. Ecosyst. Environ. 2008, 128, 167-176. [CrossRef]

18. Pansak, W.; Hilger, T.; Lusiana, B.; Kongkaew, T.; Marohn, C.; Cadisch, G. Assessing Soil Conservation Strategies for Upland Cropping in Northeast Thailand with the WaNuLCAS Model. Agroforest. Syst. 2010, 79, 123-144. [CrossRef]

19. Mutsaers, H.J.W. A Field Guide for On-Farm Experimentation; IITA: Ibadan, Nigeria, 1997.

20. Paleari, S. Is the European Union Protecting Soil? A Critical Analysis of Community Environmental Policy and Law. Land Use Policy 2017, 64, 163-173. [CrossRef]

21. Chowaniak, M.; Głąb, T.; Klima, K.; Niemiec, M.; Zaleski, T.; Zuzek, D. Effect of Tillage and Crop Management on Runoff, Soil Erosion and Organic Carbon Loss. Soil Use Manag. 2020, 36, 581-593. [CrossRef]

22. Agegnehu, G.; Ghizaw, A.; Sinebo, W. Yield Performance and Land-Use Efficiency of Barley and Faba Bean Mixed Cropping in Ethiopian Highlands. Eur. J. Agron. 2006, 25, 202-207. [CrossRef]

23. Kumar, V.; Gathala, M.K.; Saharawat, Y.S.; Parihar, C.M.; Kumar, R.; Kumar, R.; Jat, M.L.; Jat, A.S.; Mahala, D.M.; Kumar, L.; et al. Impact of Tillage and Crop Establishment Methods on Crop Yields, Profitability and Soil Physical Properties in Rice-Wheat System of Indo-Gangetic Plains of India. Soil Use Manag. 2019, 35, 303-313. [CrossRef]

24. Thomas, G.A.; Dalal, R.C.; Standley, J. No-till Effects on Organic Matter, PH, Cation Exchange Capacity and Nutrient Distribution in a Luvisol in the Semi-Arid Subtropics. Soil Till. Res. 2007, 94, 295-304. [CrossRef]

25. Sogbedji, J.M.; van Es, H.M.; Agbeko, K.L. Cover Cropping and Nutrient Management Strategies for Maize Production in Western Africa. Agron. J. 2006, 98, 883-889. [CrossRef]

26. Shafi, M.; Bakht, J.; Jan, M.T.; Shah, Z. Soil C and N Dynamics and Maize (Zea May L.) Yield as Affected by Cropping Systems and Residue Management in North-Western Pakistan. Soil Tillage Res. 2007, 94, 520-529. [CrossRef]

27. Zuazo, V.H.D.; Martínez, J.R.F.; Pleguezuelo, C.R.R.; Raya, A.M.; Rodríguez, B.C. Soil-Erosion and Runoff Prevention by Plant Covers in a Mountainous Area (SE Spain): Implications for Sustainable Agriculture. Environmentalist 2006, 26, 309-319. [CrossRef]

28. Quinkenstein, A.; Woellecke, J.; Böhm, C.; Grünewald, H.; Freese, D.; Schneider, B.U.; Hüttl, R.F. Ecological Benefits of the Alley Cropping Agroforestry System in Sensitive Regions of Europe. Environ. Sci. Policy 2009, 12, 1112-1121. [CrossRef]

29. Midya, A.; Bhattacharjee, K.; Ghose, S.S.; Banik, P. Deferred Seeding of Blackgram (Phaseolus Mungo L.) in Rice (Oryza Sativa L.) Field on Yield Advantages and Smothering of Weeds. J. Agron. Crop Sci. 2005, 191, 195-201. [CrossRef]

30. Dhima, K.V.; Lithourgidis, A.S.; Vasilakoglou, I.B.; Dordas, C.A. Competition Indices of Common Vetch and Cereal Intercrops in Two Seeding Ratio. Field Crops Res. 2007, 100, 249-256. [CrossRef]

31. Bedoussac, L.; Justes, E. Dynamic Analysis of Competition and Complementarity for Light and N Use to Understand the Yield and the Protein Content of a Durum Wheat-Winter Pea Intercrop. Plant Soil 2010, 330, 37-54. [CrossRef] 